\title{
"What happens to my Facebook profile when I die?" : Legal Issues Around Transmission of Digital Assets on Death
}

\author{
Lilian Edwards ${ }^{1}$ and Edina Harbinja ${ }^{2}$
}

\section{A. Introduction}

This chapter aims to explore some of the major legal issues pertaining to transmission of digital assets on death. "Digital assets" within this chapter are defined widely and not exclusively to include a huge range of intangible information goods associated with the online or digital world: including social network profiles e.g. on Facebook, Twitter, Google + or Linked In; emails, tweets, databases etc; in-game virtual assets (e.g., as bought, found or built in worlds such as Second Life, World of Warcraft, Lineage, etc); digitised text, image, music or sound, such as video, film and e-book files; passwords to various accounts associated with provisions of digital goods and services, either as buyer, user or trader (e.g. to eBay, Amazon, Facebook, YouTube etc); domain names; 2D or 3D personality-related images or icons such as user icons on LiveJournal or avatars in Second Life; and not excluding the myriad types of digital assets emergent as commodities capable of being assigned worth (e.g. "zero day exploits" or bugs in software which antagonists can exploit $\left.{ }^{3}\right)$.

In emerging legal discourse, disputes over digital assets on death can be usefully divided as related to either their pure economic value, or what might be called their dignitary, personal or non-economic value. Domain names, for example are an obvious example of an economic asset which may be crucial to the branding and thus the profitability of a business. In a family business, not only who inherits the domain name itself, but also who gets the email notifying of the upcoming need to re-register, may be controversial issues. Similarly many outlet businesses nowadays operate exclusively from eBay and, again, who inherits that account (i.e. the password and login), the money attached to the account, and any connected ongoing auctions will be a serious matter. Virtual assets in game worlds often represent the fruit of thousands of hours of labour (if game playing can be called labour ${ }^{4}$ ) and there is already a substantial ethical and legal literature around their value, sale and conditions for transferability ${ }^{5}$. Photos, blogs and text (e.g. spontaneous poems) within social network

\footnotetext{
${ }^{1}$ Professor of E-Governance, University of Strathclyde, Glasgow.

${ }^{2} \mathrm{PhD}$ candidate, University of Strathclyde. Ms Harbinja's research is funded by the Horizon Digital Economy Hub, Nottingham, for which both authors express their gratitude; and forms part of the work programme of the RCUK funded Centre for Creativity, Regulation, Enterprise and Technology (CREATe - see www. create.ac.uk).

${ }^{3}$ Edwards L Law and the Internet ( ${ }^{\text {rd }}$ edn, Hart, 2009), ch 21, pp 687-690.

${ }^{4}$ Playing games as piecework to create commercially transferable assets (or levels of play) is often called goldfarming, and usually done by developing world players on low wages to sell to time-poor developed world players. See further Dibbell J "The Life of a Chinese Goldfarmer", New York Magazine, June 17, 2007 available at http://www.nytimes.com/2007/06/17/magazine/17lootfarmers-t.html? r=0.

${ }^{5}$ See e.g. Castronova E "Virtual Worlds: A First-Hand Account of Market and Society on the Cyberian Frontier" CESifo Working Paper Series No. 618 (2001), available at SSRN: http://ssrn.com/abstract=294828 , Fairfield J "Virtual Property" B.U.L.Rev. (2005) 85, Blazer C “The Five Indicia of Virtual Property" Pierce Law Review, Vol. 5 (2006), Lastowka G and Hunter D "The Laws of the Virtual Worlds" Cal. L. Rev. 92 (2004) 1, Heeks R "Understanding "Gold Farming" and Real-Money Trading as the Intersection of Real and Virtual Economies" Virtual Economies, Virtual Goods and Service Delivery in Virtual Worlds, February 2010, Volume 2, Number 4, Westbrook T.J. “Owned: Finding a Place for Virtual World Property Rights” 2006 MICH. ST. L. REV. 779, Vacca R "Viewing Virtual Property Ownership Through the Lens of Innovation” 76 TENN. L. REV (2008) 33
} 
profiles by celebrities - or those who die and later become famous - are likely soon to be of economic value, just as author's letters and unpublished novels ${ }^{6}$ are today.

But such assets may also be of what one might call sentimental value. Millions of photos exist on Flickr, Picasa, etc which are of very little value to anyone but the accountholder's immediate friends and family - but to them they may be priceless. Similarly, access to the emails of a deceased family member may be of desperate importance to the bereaved, and this issue more than any has sparked public and legislative attention to the issue of digital assets, intermediary platforms and death (see below, sec. B, p. 6). Another crucial modern phenomenon is the trend towards "memorialisation" of social network profiles on Facebook and the like ${ }^{7}$; effectively turning them into shrines to the memory of the deceased, where friends leave last messages and other friends gather to read them. In such cases, although money is not (usually) the issue, emotions can run very high and conflicts develop (do the friends or the parents decide if the profile is memorialised? What if the profile tells people something about the deceased the parents would rather suppress e.g. homosexuality, atheism, suicide?) and the first litigation relating to access to, and possession of, social network profiles is also beginning to percolate through ${ }^{8}$.

Finally it is worth noting that society in general as well as specific heirs, family and friends has an interest in the legacy of the dead; e.g. authors' letters (or emails, or blogs) have value to historians, scholars and critics as well as a market value to collectors. The range of stakeholders involved in digital assets cases is thus disparate and by no means limited to those in a contractual relationship with service providers ${ }^{9}$.

In all types of cases, the legal issues around access, control, ownership and transmission are complex, and worse still, such answers as there are may vary considerably from legal system to legal system. It is important to note the law does not start here from a blank canvas. To some extent, existing laws will already partially regulate the issues. Almost all legal systems have rules relating to the transmission of property on death, under the name of wills and testaments law, succession, probate etc. Succession law is usually divided into what the law says when a will has been made by the deceased (testacy) and what happens when no will exists (intestacy). The law regulating the procedure to wind up the deceased's estate - the ingathering and distribution of assets to heirs or legatees - is a separate branch of law again, usually called executry or administration. Unhelpfully, succession laws tend to be very localised - e.g. the substantive laws relating to transmission of assets on death vary wildly even between, say, the various United States, England and Wales, and Scotland, which are at

\footnotetext{
${ }^{6}$ See e.g. "The inside story of Nabokov's last work", Guardian 17 November 2009 concerning the publication of a posthumous novel against Nabokov's wishes at http://www.guardian.co.uk/books/2009/nov/17/inside-storynabokov-last-work; see MSN News, 13 December 2012 at http://news.msn.com/pop-culture/charlotte-bronteletters-sell-for-dollar296000-2 reporting the sale of 6 letters by Jane Austen for nearly $\$ 300,000$ and the sale of a previous unpublished novel by her for $\$ 1.1 \mathrm{~m}$ in 2011.

7 "Memorialisation" usually involves freezing all posts at time of death, preventing adding of any new Friends and rejecting further login attempts, but allowing existing Friends of the deceased to add comments. See e.g. Kasket E "Continuing bonds in the age of social networking” Bereavement Care, 31(2) (2012) 62-69 or Stokes P 'Ghosts in the Machine: Do the Dead Live on in Facebook?' Philos. Technol. (2012) 25:363-379. As of March 2012 it was estimated there are at least 30 million profiles on Facebook relating to dead people: Readwrite, March 62012 at http://readwrite.com/2012/03/06/i_wanna_live_forever_or_how_we_die_on_social_netwo .

${ }^{8}$ See e.g. Facebook discovery case, below n 77; Janna Moore Morin case discussed at http://www.deathanddigitallegacy.com/2012/02/20/nebraska-is-latest-state-to-address-digital-legacy/, February 20 2012, (conflict between family and friends over whether FB page should be deleted or memorialised, see also BBC video interview with family, 31 January 2012, at http://www.bbc.co.uk/news/magazine-16801154 ); see generally Mazzone J "Facebook’s Afterlife" (2012) 90 N Carolina Law Rev 143.

${ }^{9}$ See further Desai D. "Property, Persona, and Preservation" (2008) 81 Temple Law Review 67.
} 
least all three common law jurisdictions (though Scotland has considerable civilian influence). Civilian legal systems (eg as found in the nations of Continental Europe, Latin America, Louisiana, Quebec and Japan) differ even further. These differences matter: in one system, the spouse of the deceased may inherit or have the right to occupy the family home no matter what a will says - in others, the will may reign triumphant. In some systems, step-children may inherit nothing on intestacy, while in others they may be equal to full-blood children. Some attempts have been made to harmonise a few aspects of succession law globally - e.g. as discussed below, the laws on recognition of grants of administration obtained abroad in relation to assets in the local jurisdiction - but very little of the basic substantive law has been globally harmonised. As we shall see later, this means difficult jurisdictional problems are likely to arise in the nature of digital assets, for example, if an English person dies in England but with a profile on Facebook, a company whose HQ is in California but whose servers may be distributed globally. We touch briefly on this issue at section $\mathrm{E}$.

The key question is how far digital assets fit well into these existing legal paradigms, complex as they are, and whether new law is needed. Two preliminary issues complicate the matter. First, in general, assets only fall into the estate of a deceased if they are "property". Property law, like succession law, is a well-established and ancient branch of private law. It has also been annotated by more modern legal conceptions including intellectual property (IP) law, data protection (DP) law, privacy law and information law. Property is most often recognisable as to what transmits on death. It has restrictions. In most systems, not all things we may want, or think we own, are property, although where the line is drawn is one of the most difficult issues in private law. Some items cannot be owned as they belong to all of us: the air and the high seas are usually in this category. More relevantly to digital assets, some items are too evanescent to be property. The hope of a future gain - e.g. an option to buy future stock, held by an employee when they die - may or may not convert into an item in their probate inventory, depending on the legal system and the exact details. The same may apply to a future right to sue on behalf of the deceased if he or she was libelled or wronged or dismissed from employment without cause during their lifetime. In many legal systems, such claims are viewed as personal to the deceased and title to sue in such cases dies with the wronged person and will not transmit to their heirs.

Some licences - contractual rights to use, as are commonly "sold" in relation to digital music or intellectual property (IP) in general - are explicitly given only for limited periods of time which may mean they expire on death (or earlier) and so do not form part of the estate of the deceased. This point is very relevant to inheritance of MP3s downloaded from e.g. iTunes, or e-books downloaded to a Kindle. Finally, some assets are so novel it is simply hard to tell if they can be categorised as property, even if regularly "sold" or valued, and if so, what kind of property. The "zero day exploits" mentioned above may fall into this character, as might be on-line reputations e.g. the "karma" on Slashdot of a commenter, or a trader's cumulative rating on eBay. We discuss some of these problems below, using emails and MP3s bought from iTunes as illustrative examples.

The second key complication is that many important digital assets are controlled, both practically and legally, by intermediaries. This is true in the offline world as well sometimes e.g. access to a bank account is controlled by the bank when the user dies - but it is much less common than in the online world. Access to Facebook profiles, for example, is entirely controlled by Facebook. A user cannot set up a profile there without entering a contract with Facebook. This contract is usually formed when a user clicks "I accept" or similar, and is therefore deemed to have read and accepted the terms and conditions set by Facebook. (Such agreements - whether known as "end user license agreements" or EULAs (as is common in 
games and virtual worlds); or terms and conditions (T\&C); or Acceptable Use and Privacy Policies are all basically legal contracts.) When the user dies, control of the profile is still effectively with Facebook. They can close or delete or memorialise the profile, according to their own internal rules or norms, while the heirs may not even be able to read it if they are not FB users, or even if they are if they were not "Friends" with the deceased (and how many young people have their mother, say, as a Friend on Facebook?) Legally as far as Facebook is concerned, the relationship between them and the user, even after death, is primarily regulated by contract. The contract may simply not contain any rules on what happens on death Facebook do give some insight into their internal rules ${ }^{10}$ but many service provider contracts are simply blank on the matter, which may mean disputes are left to the discretion of abuse teams, or similar. Even where rules do exist though, there is a patent potential for conflict on death between the rules of contract and the rules of succession/executry. This major problem was first explored in case law in the celebrated Ellsworth and Yahoo! case, discussed in full below at section $\mathrm{B}$.

A connected and less often aired problem is that contract rules are a matter of private bargaining not social policy. While inheritance laws may have evolved to try to balance the interests of, say, parents and spouse of the deceased, or spouse and best friend, or even society (e.g. ultimus haeres rules), contract is unlikely to think about the public good or what value society places on family ties. This is particularly true in the context of social network or most online service contracts which are usually (as they say in consumer law) standard form contracts dictated to the user with significant imbalance of power and lack of opportunity to negotiate. In plain English, this mean that users rarely read the contracts they "sign" with online service providers and have no power to alter them even if they did; thus they are likely not to reflect their real wishes on death but merely what is commercially best for the service provider. There is often a lack of transparency as to what the service provider's rules are, and a lack of consistency as to what the rules are from one service provider to another. This is why it is quite probable that what terms if any social network providers state about transmission of user accounts may well clash with the general law of succession; and that users are likely to have no idea what happens to their profiles etc when they die.

Given the complexities described above, this chapter will mainly draw comparatively on the laws of the US and England and Wales, with a few references where relevant to EU law. In general as a matter of private law, succession and property laws in the EU are a matter for national law. Some harmonised EU law, e.g. data protection law, is however relevant. Similarly in the US, succession law is largely a state not federal matter. As already noted, the lack of international (or often even national) harmonisation in this area is a particularly acute problem when talking about "globalised" or delocalised assets such as tweets or Facebook profiles. Another key problem is the simple novelty of the area, meaning there is a lack of legal precedent as well as good practice among solicitors/lawyers. Part of the plan for future Edwards/Harbinja research is to provide a one-stop shop guide for users and lawyers seeking guidance on devolution of particular digital assets on death.

\section{B. What digital assets constitute property?}

As noted above, a first question is to ask if a digital asset is actually an item capable of being transmitted on death, i.e. does it legally constitute "property". This issue has recently been of controversy in the common law world in relation to two prevalent examples: emails, and songs downloaded from the iTunes (Apple) platform.

\footnotetext{
${ }^{10}$ See $\mathrm{n} 38$ and sec. C below.
} 
In the significant recent English case, Fairstar Heavy Transport N.V. v Adkins ${ }^{11}$, Justice Edwards-Stuart concluded that emails could not be considered as property. The case did not concern transmission on death, but rather a commercial dispute between the ex-employee of a company, and the new owners of the company who had been successful in a hostile takeover. Emails sent to Adkins in his role as company employee were crucial to the company after he left, in order that the company could defend itself in a stock market investigation in Norway, and other matters; however they had been forwarded to Adkins' private email address and deleted from the company server. The company therefore sought to attach the emails as the property of the company. The case is clearly relevant to deciding if emails are "property" for any circumstance including, as here, litigation or inquiries, but also potentially, death, divorce or bankruptcy. Drawing on previous case law relating to the general status of information as property in the context of hard copy letters, Edwards-Stuart $\mathrm{J}$ drew a clear distinction between any physical container and the information it carried:

"..there is or may be an important distinction between the physical object which carries the information - for example, a letter - and the information which that object conveys. A letter, which consists of paper together with the ink of the writing which is on it, is clearly a physical object that can be owned. However, it does not follow from this that the information which the letter conveys is also property that is capable of being the subject of a proprietary claim (for this purpose I leave aside the possibility of any claim arising out of copyright in respect of the contents of the letter). ${ }^{12}$

Justice Edwards-Stuart reached this conclusion by hypothesising as to what would follow if the content of an e-mail was deemed capable in law of being property. He saw five possible options:

(1) that title to the content remains throughout with the creator (or his principal);

(2) that, when an e-mail is sent, title to the content passes to the recipient (or his principal) - this being by analogy with the transfer of property in a letter when one person sends it to another;

(3) as for (1), but that the recipient of the e-mail has a licence to use the content for any legitimate purpose consistent with the circumstances in which it was sent;

(4) as for (2), but that the sender of the e-mail has a licence to retain the content and to use it for any legitimate purpose; and

\footnotetext{
${ }^{11}$ [2012] EWHC 2952 (TCC).

12 "In my judgment it is clear that the preponderance of authority points strongly against there being any proprietary right in the content of information, and this must apply to the content of an e-mail, although I would not go so far as to say that this is now settled law. Some of the observations that I have quoted are in terms that are less than emphatic and, of course, the two contrary views in Boardman v Phipps are entitled to significant weight." Fairstar, para 58; see also Lord Upjohn in Boardman v Phipps [1967] 2 AC 46, at 127, 275; Lord Walker of Gestingthorpe in Douglas v Hello! Ltd [2008] 1 AC 1: "That observation still holds good in that information, even if it is confidential, cannot properly be regarded as a form of property."; Force India Formula One Team v 1 Malaysian Racing Team [2012] EWHC 616 (Ch)
} 
that title to the content of the message, once sent, is shared between the sender and the recipient and, as a logical consequence of this, is shared not only between them but also with all others to whom subsequently the message may be forwarded. ${ }^{13}$

When discussing these options, the judge drew attention to the unwanted consequences which would necessarily follow if the information in emails was deemed "property". For option (12), where the creator of the email content retains property in it, he noted that:

The implication of adopting option (1) is that in principle the creator of an e-mail would be able to assert his title to its contents against the entire world. If that were so, one has to ask what it would involve in practice. It would be very strange - and far reaching - if the creator of an e-mail could require any recipient of it, however far down the chain, to delete it (this would have to be the remedy because the content of an e-mail is not something that one can simply return). But if he cannot do this, what is the use of having this proprietary right? ${ }^{14}$

For option (2), when the recipient has the property right in the email content, he argued:

The implication of adopting option (2) is that the creator of the e-mail would cease to have any right in its contents from the moment he sent it. It would seem to follow from this that the recipient would be entitled to ask the sender (in this case the creator) of the e-mail to delete it. Logically, the same would apply down the line so that the only person entitled to the contents of a particular e-mail would be the last recipient. However, if the initial e-mail was sent to several recipients, some of whom forwarded it to others, the question of who had the title in its contents at any one time would become hopelessly confused. ${ }^{15}$

Finally, he concluded rather sensibly:

For all these reasons I can find no practical basis for holding that there should be property in the content of an e-mail, even if I thought that it was otherwise open to me to do so. To the extent that people require protection against the misuse of information contained in e-mails, in my judgment satisfactory protection is provided under English law either by the equitable jurisdiction to which I have referred in relation to confidential information (or by contract, where there is one) or, where applicable, the law of copyright. There are no compelling practical reasons that support the existence of a proprietary right - indeed, practical considerations militate against it. $^{16}$

Despite the sense in the judgment, and the line of English cases and other authority generally repelling the notion of information as property on which it draws ${ }^{17}$, the implications for transmission of emails on death may be problematic. If neither mail senders nor recipients have property rights in the email content, then it seems to follow that heirs could not require copies of, nor access to, such emails from the mail host, even supposing such copies survived

\footnotetext{
${ }^{13}$ Ibid para 61

${ }^{14}$ Ibid para 65

${ }^{15}$ Ibid para 66

${ }^{16}$ Ibid para 69

${ }^{17}$ See The Law Commission Working Paper No. 110, Computer Misuse, 1988; The Law Commission, Breach of Confidence, Report on a Reference Under Section 3(L)(E) of the Law Commissions Act 1965, Report No.110
} 
after death. The position in the US seems to be different, and the leading case of Ellsworth illustrates the hard choices involved.

In the widely reported case of In Re Ellsworth ${ }^{18}$, Yahoo!, as webmail provider, initially refused to give the surviving family of a US marine killed in action the log-in rights to his email account. They plead their terms of service (i.e. the contract) which, they said, were designed to protect the privacy of the account owner by forbidding transfer of details to third parties on death ${ }^{19}$. The family argued that as his heirs, they should be able to see his emails as his "last words"- seeking access not only to those emails sent to them (or by them), but those sent by the deceased to others, as well possibly as those received by the deceased. There was a serious imminent danger that the emails would be lost forever if Yahoo!, according to its nonsurvivorship policy, deleted the account. The judge, in a judgment of Solomon, allowed Yahoo! to abide by their privacy policy in that he did not order transfer of log-in and password, but made an order requiring Yahoo! to enable access to the deceased's account by providing the family with a CD containing copies of the emails in the account. Yahoo! it seems also provided a paper copy ${ }^{20}$.

This case could be interpreted in several ways. For example it might mean Yahoo! had the property rights in the emails themselves (meaning the copies stored on their webmail server) but were subjected to a court order demanding they make the information in them available, akin, perhaps, to an order for discovery in US litigation. This view could be justified by the traditional division of rights in letters, with Yahoo! owning the emails themselves, but the deceased, as author of the emails, owning the copyright which was then transferred to the heirs on death. This would then conceivably give the heirs a right to a court order so they could access the emails, publish them or prevent further copies being made, as would be part of their rights as copyright holders. ${ }^{21}$ Alternately it could imply a right of property accruing to the author/deceased alone of both the email itself and the information it contained ${ }^{22}$, which then transmitted to the heirs of the deceased (the family). It is hard to see though, on that interpretation, why the court would not have regarded the rights of the heirs as trumping the terms of a personal obligation entered into by the deceased, and ordered full access to the account including transfer of password. (A still third option might be that the family/heirs were entitled to ingather the emails simply as administrators of the estate - but there is no evidence for this apparent from the facts made public.)

\footnotetext{
${ }^{18}$ In Re Ellsworth, No. 2005-296, 651-DE (Mich. Prob. Ct. 2005). See discussion in Baldas T. “Slain Soldier's E-Mail Spurs Legal Debate: Ownership of Deceased's Messages at Crux of Issue”, 27 Nat'1 L.J. 10, 10 (2005)

19 "No Right of Survivorship and Non-Transferability. You agree that your Yahoo! account is non-transferable and any rights to your Yahoo! ID or contents within your account terminate upon your death. Any free account that has not been used for a certain period of time may be terminated and all contents therein permanently deleted in line with Yahoo!'s policy." http://info.yahoo.com/legal/uk/yahoo/utos-173.html.

${ }^{20}$ See Associated Press release, April 21 2005, at http://www.justinellsworth.net/email/ap-apr05.htm. Note there seemed to be at least initial dubiety that Yahoo! had in fact transferred all emails in the account on to the CD.

${ }^{21}$ However see the Canadian case of Grigsby v Breckenridge (1867) $65 \mathrm{Ky}$. (2 Bush) 480, concerning hard copy letters, where the court declined to make an order giving physical access to letters written by the copyright holder (Breckenridge), even though it was agreed the owner of the physical letters (Grigsby, by lifetime gift), not being the rightsholder, would have no right to distribute or copy the copyright information contained therein ${ }^{22}$ And, presumably the copyright. One of the difficulties of both Fairstar and Ellsworth is that the courts seem unwilling to grapple with three "things" at once; property in the "wrapper" of the communication, (electronic copy of email), property in the information, and copyright in the content. One clear difference between the second and third rights is that copyright would require a degree of originality in a literary work, and be subject to limitations such as fair use/dealing and term, while "information" would have no such threshold.
} 
Darrow and Ferrera ${ }^{23}$, considering the implications of the case, agree that it does not settle the debate over whether emails are property in US law ${ }^{24}$, but argue that if emails are to be regarded as property, both US case law and emerging service provider practice seem to prefer the rights of the author to property in emails over the rights of the email service provider even if the terms of service, as in the Yahoo! case, appear to make contrary claims ${ }^{25}$. An email message is the creation of its author, and as such, should be considered the author's property and the author's rights in his e-mail should equate to rights in private hard copy letters. As in the English cases, in the US, it is fairly settled law that an author presumptively retains a copyright in physical messages authored by him, even if the physical message is sent to another; but the controversy here lies in whether this applies to email, and more so, whether when copies of emails are held by a service provider, as is the default in most webmail accounts, or sent to a third party recipient, ownership also transfers. Darrow and Ferrera hypothesise that the contractual relationship of bailment could helpfully explain the relationship between the account holder and service provider. Drawing analogies to the legal position of warehouses and safe deposit boxes, they argue that email messages are merely placed in the possession of the service provider for specific purposes, while the account holder retains full ownership of those messages. This, they conclude, defeats the argument that the emails become the property of the service provider. Accordingly, in the case of death, heirs should be able to inherit emails just as they would inherit private letters and other possessions of the deceased.

Darrow and Ferrera do admit however that this position may need modified, given the principles of freedom of contract and testation, where the deceased has made it clear he does not want the emails to go to the heirs. This seems, slightly oddly, to prioritise what terms the deceased "adds" to the contract after death, over the terms imposed ab initio by the service provider. However this might be explained, as noted above, by consumer protection policy, given the lack of opportunity for the accountholder to renegotiate the terms when entering the contract. ${ }^{26}$.

It will be interesting to see if future case law clarifies the US position, especially after Fairstar. It is notable that Darrow and Ferrara clearly hold the view that the family would have been treated badly in Ellsworth if they had not received the emails, and do not really engage with the wider consequences of declaring information to be property, such as the

\footnotetext{
${ }^{23}$ Darrow J. and Ferrera G. "Who Owns a Decedent's E-Mails: Inheritable Probate Assets or Property of the Network?" N.Y.U. J. Legis. \& Pub. Pol'y Vol. 10 (2006) 281, p. 308, Available at SSRN: http://ssrn.com/abstract=1698907

${ }^{24}$ Atwater J. "Who Owns Email? Do you have the right to decide the disposition of your private digital life?" 2006 Utah L.Rev 397, notes that Yahoo! did not appeal the order, but agreed to hand over the emails without prejudice to their position that the email account was their property (at 399).

25 "Even in the absence of such a statute, public policy considerations might allow a court to reach the same result, rendering boilerplate termination clauses ineffective in the face of society's increasing dependence on electronic communication and the significant disruption that might result if heirs are denied access to accounts.", Darrow and Ferrera (supra n 23 at 308); Note Atwater's (supra at 405) interesting suggestion that given the likely ownership of the copyright in an email by the deceased, yet the effective control by the service provider of the quasi-tangible container of the information, users should have "at least joint ownership in our email accounts during life". He also suggests that (a) the law of intestacy should create a presumption that emails cannot be deleted for a certain period of time and (b) service providers should be compelled to give access to heirs on proof of this being the likely intention of the deceased, while (c) recommending ownership of emails not be codified but left to the market via the development of a range of different service provider terms.

${ }^{26}$ Darrow and Ferrera also engage with the argument that passing property on death in emails to heirs may invade the privacy of the deceased; see further sec. F p 19 below. See also Wilkens M "Privacy and Security During Life, Access after Death: Are they Mutually Exclusive?" 201162 Hastings LJ 1037 .
} 
creation of monopolies in factual information, something which intellectual property tries to avoid; the possibly inappropriate invoking of criminal laws of theft or destruction of property; and the ability to prevent disclosure of historical facts and chill freedom of expression, something with which privacy law already struggles ${ }^{27}$.

\section{Property vs License: iTunes and e-books}

In September 2012, a story toured the Internet that Bruce Willis, the Hollywood actor, had discovered that his "extensive library" of downloaded music and films from the apple iTunes store was not legally his to leave in his will ${ }^{28}$. Aggrieved, Willis apparently planned to fight Apple in court, and was "looking into ways that might allow his three daughters, Rumer, Scout and Tallulah, to legitimately inherit it". The story later proved to be a hoax ${ }^{29}$, but it brought to public attention an issue of which most ordinary users were unaware. Apple - and other providers of music files, videos and e-books, such as Amazon.com - invariably grant "non-transferable" licenses to use content. ${ }^{30}$ This is nothing unexpected to a lawyer: intellectual property is almost always licensed on restricted terms, rather than sold to end users (otherwise those users could themselves license the content to sub-users, and take the profits from the original rightsholders). Thus for example, Amazon's terms of use state that "All licenses granted to you are non-exclusive and you do not acquire any ownership rights in the Software or Music Content." ${ }^{31}$ Apple similarly limits the use of digital files to Apple devices used by the account holder solely. ${ }^{32}$

Crucially, since licenses grant personal rights to users, these rights end on the death of the user $^{33}$ even if the contract between service provider and user is silent on the matter ${ }^{34}$. Thus, those assets are not transmissible on death nor do they form "property" in the estate of the deceased. ${ }^{35}$ In reality, this means that any provisions in a will relating to legacies of MP3s, ebooks, videos etc downloaded from commercial providers will be ineffective: an iPod can be

\footnotetext{
${ }^{27}$ Note for example the attempt of the draft EC Data Protection Regulation to balance the newly introduced "right to forget" with measures to protect the historical record and freedom of expression. See Recitals 53, 54, Art. 17, Proposal for a Regulation of the European Parliament and of the Council on the protection of individuals with regard to the processing of personal data and on the free movement of such data (General Data Protection Regulation), COM(2012) 11 final, 2012/0011 (COD)

${ }^{28}$ See Arthur C. "Bruce Willis to fight Apple over right to leave iTunes library in will", Guardian, 3 September 2012 at http://www.guardian.co.uk/film/2012/sep/03/bruce-willis-apple-itunes-library .

${ }^{29}$ See Arthur C. No, Bruce Willis isn't suing Apple over iTunes rights" Guardian, at 3 September 2012 at http://www.guardian.co.uk/technology/blog/2012/sep/03/no-apple-bruce-willis .

${ }_{31}^{30} \mathrm{http}$ ://www.amazon.co.uk/gp/help/customer/display.html/ref=footer_cou?ie=UTF8\&nodeId=1040616 .

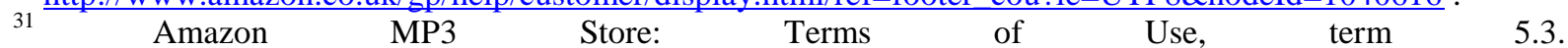

http://www.amazon.co.uk/gp/help/customer/display.html?nodeId=200285010\&pop-up=1

${ }^{32}$ see http://www.apple.com/legal/itunes/uk/terms.html\#SERVICE

${ }^{33}$ Connor J "Digital Life After Death: The Issue of Planning for a Person's Digital Assets after Death" Texas Tech School of Law Legal Studies Research Paper No. 2011-02, p. 8

${ }^{34}$ See Eastham L "Funeral music", Society for Computers and Law blog, 10 February 2012, at

http://www.scl.org/site.aspx?i=bp24899, noting that the iTunes contract's only mention of death is in relation to exclusion of liability.

${ }^{35}$ For US law see, e.g. Sherrin et al. (1987): "A will can only dispose of property, or an interest in property belonging to the testator at the time of his death, except insofar as the testator has a testamentary power of appointment over the property. Any disposition of property in which the testator has never had an interest or of property in which he had an interest at the date of his will but has since disposed of in his lifetime must fail. Therefore, any devolution of digital property in which a testator never had an interest in, or no longer has at the time of death, will not stand." p 364 in L. McKinnon "Planning for the succession of digital assets" C.L.S.Rev., Volume 27, Issue 4 (2011), pp. 362-367, or per Darrow and Ferrera: "For the purposes of federal tax law, "[p]robate assets are those assets of the decedent, includible in the gross estate under IRC $\S 2033$, that were held in his or her name at [the] time of death." supra n 23 at p 311
} 
bequeathed but not the songs on it downloaded from iTunes ${ }^{36}$. The issue is increasingly not a trivial one: a recent UK survey by cloud hosting company Rackspace found that of 2000 adults surveyed, $25 \%$ had more than $£ 200$ worth of films, video and music stored online, leading to an estimate that the value of the collective "digital inheritance" in the UK alone exceeds $£ 2.3$ billion $^{37}$. Given the further prediction that by 2020 a third of all music will be stored online, and the rising popularity of e-books, the issue of the transferability of licensed IP properties on death looks set to be a continuing controversy.

\section{Regulation by contract}

As noted already, for many significant digital assets - social network profiles, emails, virtual assets in games, text, music and video files - the first and primary means of regulation of ownership will be by contract. Many or most user or subscriber agreements do not mention transmission on death at all; but as we have already seen in relation to Yahoo! and iTunes, the terms of the contracts may still be significant to the rights of both users and their heirs.

In a brief survey of important online intermediaries in the digital assets world, what is immediately noticeable is that there is no single model of good practice. Instead for consumers there is a confusing jungle of difficult to understand terms and conditions. Facebook, in many ways the industry gold standard ${ }^{38}$, offers users options of having their profile deleted $^{39}$, or memorialised after death (see Fig 1 below), as well as the opportunity to provide a download of the deceased's account if prior consent has been given by the deceased, or if a court order is made after death, as in, most typically, probate or confirmation, but also possibly where law enforcement agencies become involved. ${ }^{40}$ Facebook however still refuse to provide heirs with the login and password to access the account itself. Notably,

\footnotetext{
${ }^{36}$ Of course in reality the person who inherits the iPod may simply continue to use it and its contents. However this would probably form a breach of the terms of service of iTunes which could mean termination of the service. Eastham, supra n 30, suggests a way round this would be to leave the iPod (or other device, e.g. a Kindle) with a legacy attached sufficient to allow the legatee to re-purchase the contents.

${ }^{37}$ See "Whose iTunes is it anyway?", Balfour and Manson, Solicitors, blog at http://www.balfourmanson.co.uk/news-events/news/archive/346/whose-itunes-is-it-anyway/ .

${ }^{38}$ Facebook's procedures for deletion and memorialisation of deceased's accounts were improved globally partly as a result of a general intervention by the Canadian Privacy Commissioner, adjudicating on formal complaints made: see "Facebook agrees to address Privacy Commissioner's concerns ", 27 August 2009, at http://www.priv.gc.ca/media/nr-c/2009/nr-c 090827_e.asp . Memorialisation also involves taking the profile out of public search results and prevents further login attempts (e.g. by scammers, or someone the deceased had shared their password with).

${ }^{39}$ See "We will process certain special requests for verified immediate family members, including requests to remove a loved one's account. This will completely remove the timeline and all associated content from Facebook, so no one can view it. For all special requests, we require verification that you are an immediate family member or executor. Requests will not be processed if we are unable to verify your relationship to the deceased. Examples of documentation that we will accept include:

The deceased's birth certificate.

The deceased's death certificate. estate.'

Proof of authority under local law that you are the lawful representative of the deceased or his/her

See https://www.facebook.com/help/265593773453448/, checked at 28 December 2012 :

See also : "In order to protect the privacy of the deceased person, we cannot provide login information for the account. However, once it has been memorialized, we take measures to secure the account." _ At https://www.facebook.com/help/359046244166395/.

${ }^{40}$ Facebook assert at https://www.facebook.com/help/265593773453448/ (checked at 28 December 2012): "We will provide the estate of the deceased with a download of the account's data if prior consent is obtained from or decreed by the deceased, or mandated by law." See further comment by Carroll E. "What happens to your Facebook account when you die?" 7 February 2012 at http://www.thedigitalbeyond.com/2012/02/what-happensto-your-facebook-account-when-you-die/
} 
this advice to heirs or family is not contained within the terms and conditions of the Facebook contract itself, but merely the "Help" section, and so is arguably not binding on Facebook or enforceable by families or heirs, but merely a statement of good practice. It is also somewhat difficult for non-legal users to find.

\section{Fig 1: Facebook's memorialisation request. ${ }^{41}$}

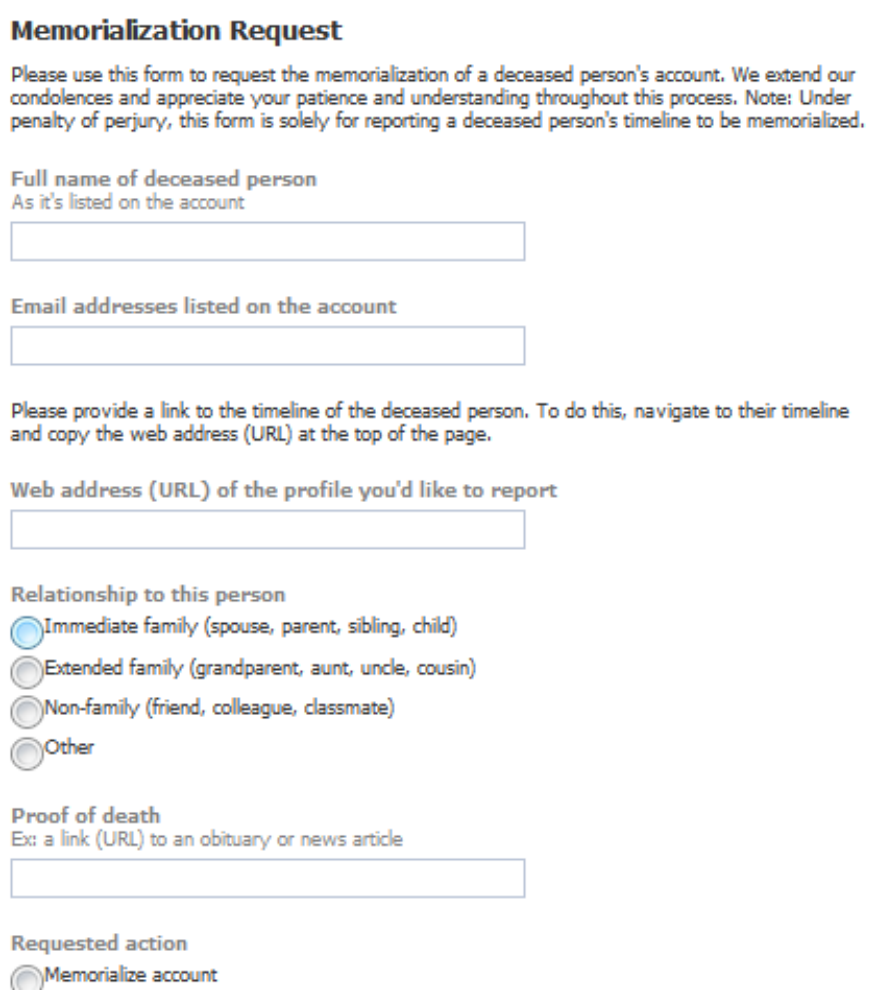

Facebook at least provide a useful selection of post-mortem remedies. Twitter by contrast only generally allows deactivation of the deceased's user account. Like Facebook, they explicitly exclude the possibility of providing login information to heirs to access the account of the deceased, leaving only discretionary possibilities of access to the content: "In the event of the death of a Twitter user, we can work with a person authorized to act on the behalf of the estate or with a verified immediate family member of the deceased to have an account deactivated. Please note: We are unable to provide login information for the account to anyone regardless of his or her relationship to the deceased." 42

Similarly, as we have seen, Yahoo! (whose policies are also shared by Flickr) also refuse to pass on logins and passwords to accounts to heirs. ${ }^{43}$ Google too appears only to contemplate passing on the contents of a Gmail account to the deceased's heirs, rather than passing login details, and even that only in exceptional circumstances ${ }^{44}$. Microsoft Hotmail on the other

\footnotetext{
${ }^{41}$ Available at https://www.facebook.com/help/contact/?id=305593649477238 at 28 December 2012. 42 See https://support.twitter.com/groups/33-report-abuse-or-policy-violations/topics/148-policyinformation/articles/87894-how-to-contact-twitter-about-a-deceased-user .

${ }^{43}$ See discussion above of Yahoo!'s terms of service and the Ellsworth case.

44 "If an individual has passed away and you need access to the contents of his or her email account, in rare cases we may be able to provide the Gmail account content to an authorized representative of the deceased user. We extend our condolences and appreciate your patience and understanding throughout this process." http://support.google.com/mail/bin/answer.py?hl=en\&answer=14300
} 
hand appear willing to offer access even to the administrators of estates of incapax, but not deceased, users ${ }^{45}$. Thus among webmail providers and social networks, a norm seems to be emerging of discretionary access to content in the accounts of deceased users, but no formal right to this, and express prohibition of transfer of account login details (which would allow family or friends to, e.g. carry on posting new content on the site, or to add new Friends).

Another key contractual area, of particular importance in online games or virtual worlds prominently featuring User Generated Content (UGC), is the ownership of assets created in these games or via these platforms. As noted above, these assets often have considerable value in the "real world" as well as sentimental value. As already noted, if the user has no property rights in assets, they a priori cannot be transmitted to heirs on death. Blizzard, the World of Warcraft provider, explicitly excludes any property rights of users in assets created or traded in the game, as well as forbidding transfers of accounts. ${ }^{46}$ By contrast, Linden Labs, provider of the virtual world Second Life, gives users relatively extensive rights in content created by users therein. ${ }^{47}$ Mazzone notes that in line with these policies, Linden Labs also allow for in game assets to be transferred and bequeathed on death ${ }^{48}$. Looking beyond virtual worlds, Instagram, recently bought by Facebook, a photo sharing site, caused Internet protests when they appeared to change their terms of service in December 2012 to acquire ownership of photos stored on their site by users. Fairly swiftly, the change (whose legal implications were in any case disputed) was reversed ${ }^{49}$. Interestingly, Google, some of whose services allow the submission of original content (e.g. home-made videos to YouTube) explicitly and very plainly disclaim any rights in the IP therein ${ }^{50}$.

\footnotetext{
${ }^{45}$ See n 98 of Mazzone, supra $n 8$.

46 "All rights and title in and to the Service (including without limitation any user accounts, titles, computer code, themes, objects, characters, character names, stories, dialogue, catch phrases, locations, concepts, artwork, animations, sounds, musical compositions, audio-visual effects, methods of operation, moral rights, any related documentation, "applets," transcripts of the chat rooms, character profile information, recordings of games) are owned by Blizzard or its licensors." See Terms of Use Agreement, last updated August 22, 2012 http://us.blizzard.com/en-us/company/legal/wow tou.html. "Blizzard does not recognize the transfer of World of Warcraft Accounts or BNET Accounts (each an "Account"). You may not purchase, sell, gift or trade any Account, or offer to purchase, sell, gift or trade any Account, and any such attempt shall be null and void. Blizzard owns, has licensed, or otherwise has rights to all of the content that appears in the Game. You agree that you have no right or title in or to any such content, including without limitation the virtual goods or currency appearing or originating in the Game, or any other attributes associated with any Account. Blizzard does not recognize any purported transfers of virtual property executed outside of the Game, or the purported sale, gift or trade in the "real world" of anything that appears or originates in the Game. Accordingly, you may not sell ingame items or currency for "real" money, or exchange those items or currency for value outside of the Game."

${ }^{47}$ Second Life Terms of Service, December 15, 2010, title 7. See especially the right to retain title to all intellectual property brought into the game, the right to delete all copies of your content from the game, and most importantly, "7.6 Linden Lab owns Intellectual Property Rights in and to the Service, except all User Content", See http://secondlife.com/corporate/tos.php?lang=en-US and commentary in Vacca supra n 5; A. B. Steinberg 'For Sale--One Level 5 Barbarian for 94,800 Won: The International Effects of Virtual Property and the Legality of Its Ownership' 37 Ga. J. Int'l \& Comp. L. 381 2008-2009; J. Gong 'Defining and Addressing Virtual Property in International Treaties' 17 B.U. J. Sci. \& Tech. L. 1012011

${ }^{48}$ Mazzone, supra n 8, citing Linden Lab Official: Death and Other Worries Outside Second Life, SECOND LIFE WIKI, at http://wiki.secondlife.com/wiki/Linden_Lab_Official:Death_and_other_worries_outside_Second_Life ${ }^{49}$ See Holpuch A. "Instagram reassures users over terms of service after massive outcry" Guardian, 18 December 2012 at http://www.guardian.co.uk/technology/2012/dec/18/instagram-issues-statement-terms-ofservice .

${ }^{50}$ Google terms of service, last modified 1 March 2012 at http://www.google.com/intl/en/policies/terms/ . "Your content in our services. Some of our Services allow you to submit content. You retain ownership of any intellectual property rights that you hold in that content. In short, what belongs to you stays yours." Note the YouTube terms of service modify this to require the user to grant a license to YouTube. YouTube terms of service, last modified 9 June 2010, 7.2. (The license terms are described in section 8).
} 
Of course as seen in the Ellsworth case, contractual terms are not always the last word, and may be struck down as unconscionable or unreasonable when between consumers and businesses, as well as trumped by court orders e.g. in executry. How are the upcoming inevitable conflicts between terms of service, and court orders to be resolved in any predictable fashion? Given the norm of non-transferability of account access details, it may not be ethical for estate planners or lawyers to simply advise their client to prepare a will that passes on usernames and passwords, a commonly recommended strategy (nor is it ideal from a security point of view during life). Darrow and Ferrera assert that digital assets should generally fall into the "gross estate" of a deceased ${ }^{51}$, and therefore be considered "probate assets that [are] subject to the same inheritability rules as other probate assets." but do not really attack head-on the difficulties of a conflict between terms of service and court orders ${ }^{52}$. The issue is crucial as in some jurisdictions, accessing an account contrary to the terms of service may be seen as unauthorised access, hacking or similar crimes ${ }^{53}$. Lamm, a US estate planning attorney, argues that even where an executor has the authority of the court to access the deceased's assets, he may still not be authorised to access the account under the Terms of Service contract, and any such attempt may be construed as "unauthorised access" under criminal law. ${ }^{54}$ Such breach of terms of service might also trigger the service provider to close the account, thus destroying the virtual assets. In addition, the US Electronic Communications Privacy Act 1986 prevents a service provider from disclosing stored communications unless a court order is made. ${ }^{55}$ In a recent case, a US court refused to grant access to family to details in the Facebook records of the deceased, based on the protection provided by this Act. ${ }^{56}$

By contrast, in England and Scotland, it is thought more likely to be assumed that a court order for probate or confirmation takes precedence over any lifetime contractual terms restricting access. Guidance might be drawn here from practice relating to executors or administrators ingathering the contents of bank accounts (both high street and online) where longstanding procedures exist to ease distribution of the estate even if only the deceased or perhaps his spouse or partner had the contractual right to access before death ${ }^{57}$. Finally it is worth noting that Facebook's Memorialisation Request (above, Fig 1) grants authority to a selection of family and associates of the deceased which may not match the preferential list of executors in intestacy in every legal jurisdiction (certainly not in Scotland, for example ${ }^{58}$ ), nor

\footnotetext{
${ }^{51}$ The Internal Revenue Code defines the "gross estate" as "the value at the time of [decedent's] death of all property, real or personal, tangible or intangible, wherever situated." Darrow and Ferrera, supra n 23.

52 Darrow and Ferrera, supra note 23, at note 151.

${ }^{53}$ See for example in the UK, the Computer Misuse Act s 1; in the US, the Electronic Communications Privacy Act of 1986 (ECPA), 18 U.S.C. $§ 2510-22$

54 Computer Fraud and Abuse Act, § 1030(a)(2)

55 See Kulesza A "What Happens to Your Facebook Account When You Die?", February 3, 2012, at http://blogs.lawyers.com/2012/02/what-happens-to-facebook-account-when-you-die/ .

${ }^{56}$ See In re Request for order requiring Facebook, inc. to produce documents and things, Case No: C 12-80171 LHK (PSG), 9/20/201, and see further below at sec E p 16.

${ }^{57}$ For example, the general principle in Scotland is that the executor acquires the same title as the deceased had to ingather the entire estate including both tangible property, heritable and moveable, and debts. See eg Gretton GL and Steven AJM Property, Trusts and Succession (Tottel, 2009), paras 25.45ff. Note however Wilkens (supra n 26) account of US executry practice, where she claims ingathering electronic bank accounts and similar financial information is extremely difficult for executors in the US because of the privacy safeguards imposed by inter alia the Gramm-Leach-Bliley Act and the Electronic Communications Privacy Act. She points as a result to a defensive and routinised attitude by financial institutions and service providers who veer on the side of privacy for fear of regulatory breach. We return to this point when discussing post mortem privacy below at sec F.

${ }^{58}$ See Succession (Scotland) Act 1964 as amended.
} 
any named executor in a will. This too may be fertile ground for conflicts in executry courts in future years.

\section{Tailored legislation}

The United States of America, or more precisely, some of its states, have been the most active nations in legislating to regulate transmission of digital assets on death. As noted above, succession and property fall within the state rather than federal jurisdiction in the US. In the UK, by contrast, there seems as yet neither statute nor case law in this area.

So far, six US states have attempted to regulate the area, starting from 2005. These states are the following: Connecticut (2005 law, mandating that e-mail providers should provide copies of all e-mails to the executor or administrator of a decedent's estate) ${ }^{59}$, Indiana (2007 law, requiring "any person who electronically stores the documents or information of another person" to "provide to the personal representative of the estate of a deceased person, who was domiciled in Indiana at the time of the person's death, access to or copies of any documents or information of the deceased person stored electronically by the custodian.") ${ }^{60}$, Rhode Island (2007 law, referring to e-mail accounts only, as with the Connecticut statute) ${ }^{61}$, Oklahoma (2010 law, referring to access to accounts on any social networking website, any microblogging or short message service website or any e-mail service websites) ${ }^{62}$, Idaho (2011 law, based on the Oklahoma law, referring as well to accounts on any social networking website, any microblogging or short message service website or any e-mail service website) ${ }^{63}$, Nebraska (2012 bill proposal, text of provisions based on Oklahoma and Idaho laws) ${ }^{64}$. We will probably soon witness other states enacting similar laws, based on the quoted examples. At the moment, however, in other states the law would depend on the conflict between contract law and court orders made in executry as discussed above. ${ }^{65}$

It is obvious from this brief overview of US legislation that state coverage is very patchy and that not all the digital assets are included therein; some of the more economically significant assets : e.g. domain names, eBay or Amazon accounts, iTunes collections, gaming accounts etc cannot be subsumed under the definitions in these laws. In general these laws seem to have been inspired by the publicity around the Ellsworth case and similar controversies and resemble "moral panic" laws in being partial and responsive, rather than comprehensive and future-proofed. Some laws, eg, the Oklahoma statute, explicitly grant the executor power only "where otherwise authorized." It is not always clear what would result if service providers challenged efforts to apply the law where it appeared to violate terms of service. There might also be jurisdictional clashes where the law of the state where the deceased died domiciled or resident was not the same as the law governing the service provider contract. ${ }^{66}$

\footnotetext{
${ }^{59}$ Conn. Gen. Stat. § 45a-334a.

${ }^{60}$ Ind. Code $\$ 29-1-13-1.1$.

${ }^{61}$ Rhode Island General Laws Chapter 33-27

${ }^{62}$ "The executor or administrator of an estate shall have the power, where otherwise authorized, to take control of, conduct, continue, or terminate any accounts of a deceased person on any social networking website, any microblogging or short message service website or any e-mail service websites. “ 58 Okla. Stat. Ann. § 269

${ }^{63}$ Idaho Statutes $\S 15-3-715(28)$ and $\S 15-5-424(3)(\mathrm{z})$

64 See "Nebraska is Latest State to Address Digital Legacy", February 20, 2012, at http://www.deathanddigitallegacy.com/2012/02/20/nebraska-is-latest-state-to-address-digital-legacy/

${ }^{65}$ see e.g. Connor supra n 33

${ }^{66}$ Darrow and Ferrera supra n 23 p 297 ; see section E below.
} 
The answer to this patchwork coverage and possible conflicts of law clashes may be harmonisation within the US. In July 2012 the US Uniform Law Commission formed the Drafting Committee on Fiduciary Access to Digital Assets. ${ }^{67}$ The goal of the Committee is to draft a free-standing act and/or amendments to Uniform Law Commission acts, such as the Uniform Probate Code, the Uniform Trust Code, the Uniform Guardianship and Protective Proceedings Act, and the Uniform Power of Attorney Act, that will vest fiduciaries with at least the authority to manage and distribute, copy or delete, and access digital assets. While this initiative is welcome, it is to be hoped a new model law will not cookie-cut the provisions from one of the existing statutes but make an attempt to consider the full range of digital assets as well as clarifying possible conflicts between contract and executry law, and between heirs, family and friends.

\section{E. Jurisdiction, applicable law and digital assets}

As noted above, jurisdiction and applicable law are likely to be significant problems in succession issues involving digital assets. In terms of jurisdiction in succession, a court's authority, depending on local laws, may be based on the the situs of the asset within the jurisdiction, as well sometimes as the domicile/habitual residence of the deceased, or choice of forum provision in any will ${ }^{68}$. Similarly, when a court seeks to determine what law applies to the devolution of a particular digital asset, it may be crucial if it is regarded as fitting into categories such as movables or immovable, tangible or intangible, personal or real property etc. It may seem axiomatic that digital assets are moveable; but there has already been some categorisation of virtual spaces as "land" where tortious trespass can take place in a controversial run of US cases ${ }^{69}$. Similarly, many users regard "land" in Second Life as more akin to real-world land than intellectual property.

Taking an example, what happens if an English domiciled, and married, player of Second Life (owned by Linden Lab) dies intestate leaving substantial in-game assets, including a magic shield worth $\$ 1000$ and virtual "land" worth $\$ 10,000{ }^{70}$ and his English executor tries to ingather the estate? The English courts will accept jurisdiction where there is good reason which has been interpreted to include on grounds of the last domicile of the deceased ${ }^{71}$. However in terms of applicable law, under English common law, succession to the movables of a person who dies intestate will be governed by the law of his domicile at the date of his death. The succession to the immovables of a person who dies intestate will be governed by the law of the state in which the immovable are situated ${ }^{72}$. The Second Life terms of service meanwhile state that any disputes: "shall be governed by the laws of the State of California

\footnotetext{
${ }^{67}$ At the US Uniform Law Commission 2012 Annual Meeting in Nashville, Tennessee, July 13-19 2012, see http://uniformlaws.org/Narrative.aspx?title=QR\%20Issue\%2012\%20\%3E\%20New\%20Committees

${ }^{68}$ See generally Anton Private International Law (W.Green/SULI, $3^{\text {rd }}$ edn, 2011), ch 23; Clarkson and Hill eds, Jaffey on the Conflict of Laws(2nd edn , 2002) p 509, saying that the English courts are primarily prepared to appoint an executor as personal representative where the deceased has left property in England but may also do so if other good reasons exist eg testator died domiciled in England.

${ }^{69}$ Ticketmaster Corp., et al. v. Tickets.com, Inc No CV 99-7654, 2000 US Dist LEXIS 12987 dt (CD Cal 27 March 2000), eBay v Bidder's Edge Inc 100 F Supp 2d 1058 (ND Cal 2000), Intel Corp. v. Hamidi 30 Cal. 4th 1342 (2003), or commentary in Lemley M.A. "Place and Cyberspace" CLR, Vol. 91 (2003), 521, Available at SSRN: http://ssrn.com/abstract=349760

${ }^{70}$ Or the equivalent in Linden Dollars, which are a tradeable currency: see discussion at http://en.wikipedia.org/wiki/Economy of_Second_Life where the Second Life economy was valued at $\$ 567 \mathrm{~m}$ in 2009.

${ }^{71}$ See Jaffey, supra n 68.

${ }^{72}$ Ibid at 519, nn 151 and 152.
} 
without regard to conflict of law principles or the United Nations Convention on the International Sale of Goods. Further, you and Linden Lab agree to submit to the exclusive jurisdiction and venue of the courts located in the City and County of San Francisco, California" ${ }^{73}$.

This latter clause leaves a patent conflict between the English and Californian courts in relation to jurisdiction ${ }^{74}$; and even if this can be settled, a possible dispute over whether English or Californian law applies to the devolution of both the sword and the virtual land. Since California is a state with, inter alia, rules relating to community of property between married persons ${ }^{75}$ very different from English law, this could raise serious difficulties. Such problems beset international succession disputes, and are not insuperable: but it is highly unlikely either the average game player or amateur executor or even family solicitor would know how to handle them. Nor is it clear if the games player could avoid these difficulties by making a will (and it should be remembered that most young people in any case die intestate, according to various country statistics ${ }^{76}$ ).

In testate succession, attempts have been made to achieve international harmonisation in some respects. For example, the Hague Convention 1961 on the Conflicts of Laws Relating to the Form of Testamentary Dispositions has simplified the issue of what formalities a will must meet before it can be recognised by a foreign court. The Convention was ratified in the UK by the implementation of the Wills Act 1963 and came into force on 5 January 1964. The US, however, has not signed this Convention. At EU level, a Regulation on Jurisdiction and Applicable Law has harmonised various matters, and created a European Certificate of Succession. ${ }^{77}$ The Regulation comes into force from August 2015. The Regulation, like the Hague Convention, simplifies procedures in recognising foreign wills and succession instruments, but does not deal with substantial issues such as what assets are property that can be bequeathed ${ }^{78}$.These are matters normally seen as reserved to domestic jurisdictions and thus defy harmonisation.

\footnotetext{
${ }^{73}$ Second Life, Terms of Service, last stated at December 5 2010, rule 12.2, at http://secondlife.com/corporate/tos.php\#tos 12 .

${ }^{7474}$ Note of course though that jurisdiction clauses can be challenged on consumer protection grounds and indeed a Second Life mandatory arbitration clause has already been struck down: see Bragg v Linden Labs 487 F. Supp. 2d 593 (E.D.Penn. 2007).

${ }^{75}$ For some wonderful hypothesising as to distribution of virtual assets in community property divorces, see Richardson S.B. "Classifying Virtual Property in Community Property Regimes: Are My Facebook Friends Considered Earnings, Profits, Increases in Value, or Goodwill?” (2011) 85 Tulane Law Review 717. Note that community of property also affects division on death in some US states including California, see eg guidance at http://www.ca-trusts.com/intestate.html .

${ }^{76}$ For example, nearly $60 \%$ of adults in England and Wales have not made a will - see Thornhill J "Die intestate and your loved ones will be left to untangle your legacy" 28 July 2012, at

http://www.thisismoney.co.uk/money/pensions/article-2180242/Die-intestate-loved-ones-left-untanglelegacy.html . Note also the possible effect of the EC Regulation on Succession, $n 77$ infra, should the UK choose to ratify it.

${ }^{77}$ EU Regulation 650/2012 of the European Parliament and of the Council of 4 July 2012 on jurisdiction, applicable law, recognition and enforcement of decisions and acceptance and enforcement of authentic instruments in matters of succession (the "Succession Regulation"): L 201/107, 27.7.2012.

${ }^{78}$ Ibid, art $2(\mathrm{k})$. Note that the UK has not yet agreed to opt in to the Regulation, which would change the law in significant ways eg the applicable law relating to succession would be in principle that of the country where the deceased died resident. The Regulation does contain some provisions on validity of choice of forum and law clauses entered into by the deceased, although within the limited context of choices of EU states.
} 
Finally, a real not hypothetical recent case in California, In re request for order requiring Facebook, Inc. to produce documents and things ${ }^{79}$, illustrates the complexities that may arise in cases regarding different jurisdictions and digital assets, in civil litigation generally, not just executry. On December 20, 2008, Sahar Daftary died after falling from the twelfth floor of an apartment building located in Manchester, England. Members of her family disputed that Sahar had committed suicide and believed that her Facebook account contained critical evidence showing her actual state of mind in the days leading up to her death. Facebook refused to grant access to the account to the family without court authorisation and so the family initiated a request to subpoena the records in the Californian courts, where Facebook is based. The court found that the US Stored Communications $\mathrm{Act}^{80}$ prevents a US service provider from disclosing stored communications in civil proceedings as part of basic privacy law $^{81}$. The interests protected by the US statute extend to a foreign citizen, deceased in this case, and there was no duty to provide stored communications for the purpose of the foreign proceedings, when access would not have been granted for domestic ones. The Court held: "It would be odd, to put it mildly, to grant discovery related to foreign proceedings but not those taking place in the United States." The court, interestingly, refused to rule on whether Facebook could legitimately disclose the records to the family voluntarily, leaving both the social network and the family in an unfortunate state of uncertainty.

\section{F. Rights of heirs after death vs rights of deceased: "post mortem privacy"}

Both the US cases surveyed above - Ellsworth and In re Facebook - involve what may be called the "post mortem privacy" argument - the notion that the dead are entitled to keep their secrets after death and that this may trump the rights (if any) of the family or heirs to access or take possession of their profiles, records etc after death. This argument is particularly interesting for (a) illustrating conflicts between property rights and privacy rights and (b) raising crucial differences between legal systems, already noted, as to whether rights "personal" to deceased survive death or not. We discuss post-mortem privacy as our final topic.

Post-mortem privacy is not a recognised term of art in general succession or even privacy literature. It is however emerging as a topic of general concern ${ }^{82}$. Post-mortem privacy may be conceived narrowly within Europe as protection of a deceased's personal data in terms of the EC Data Protection Directive; or more broadly, in a global context, as preserving his or her reputation, dignity, integrity or memory.

\footnotetext{
${ }^{79}$ Supra n 56.

${ }^{80} 18$ U.S.C. $\$ 2701$.

${ }^{81}$ Supra n 56, citing Theofel v. Farley-Jones, 359 F.3d 1066, 1074 (9th Cir. 2004): "Having reviewed the papers and considered the arguments of counsel, IT IS HEREBY ORDERED that Facebook's motion to quash is GRANTED. The case law confirms that civil subpoenas may not compel production of records from providers like Facebook. To rule otherwise would run afoul of the "specific [privacy] interests that the [SCA] seeks to protect."

${ }^{82}$ See e.g. Amsterdam Privacy Conference 2012, Panel on Death and Post-Mortem Privacy in the Digital Age, Oct 8 2012, Chair: Lilian Edwards, Panellists: Edina Harbinja, Anna E. Haverinen, Damien McCallig, Elaine Kasket, http://www.apc2012.org/sites/default/files/pdffiles/APC\%20programme_0.pdf or Essers L "Online Life After Death Faces Legal Uncertainty" CIO, October 08, 2012 http://www.cio.com/article/718253/Online_Life_After_Death_Faces_Legal_Uncertainty (press report on the panel)
} 
European privacy law enshrines the concept of protection of "personal data", which is defined in art 2 of the current EC Data Protection Directive (DPD) ${ }^{83}$ as "any information relating to an identified or identifiable natural person ('data subject')". Such identification can be direct (e.g. a name or address) or indirect (eg connection of a subscriber's name to an IP address). A strong set of rights are given by DP law to data subjects, including the right to prevent the transfer or sale of personal data without grounds (including consent) and rights to access and correct personal data held by others. DP laws are implemented by each member state of the EU and are roughly harmonised though significant differences still persist in implementation. By contrast, no such omnibus rules protecting personal data exist in the US, although various sectoral sets of privacy rules make up some of the gap ${ }^{84}$.

Does the personal data of decedents attract protection under DP law? This is a controversial matter, involving issues of whether personal data is property or merely involves a liability regime for misuse. The DPD does not, as currently drafted ${ }^{85}$, explicitly require protection of the deceased's data in any context. Thus currently, the overwhelming majority of the $27 \mathrm{EC}$ DP regimes do not protect decedents` personal data. However as the Directive sets only a minimum not maximum standard, it is still open to member states to introduce some kind of post-mortem privacy protection, and some have chosen to do so. ${ }^{86}$

In Bulgaria, the law states that "In the event of death of the natural person his/her rights shall be exercised by his/her heirs." ${ }^{\text {"87}}$; while in Estonia, their Data Protection Act ${ }^{88}$, s 12 states: "The consent of a data subject shall be valid during the life of the data subject and thirty years after the death of the data subject, unless the data subject has decided otherwise." Section 13 furthermore entitles certain family members to consent to processing of personal data after the death of data subject, but not more than 30 years after death. ${ }^{89}$. But by contrast, the Swedish Data Protection Act explicitly excludes post mortem personal data protection by defining personal data as "all kinds of information that directly or indirectly may be referable to a natural person who is alive." ${ }^{, 90}$ Similarly, the UK Data Protection Act defines personal data as

\footnotetext{
${ }^{83}$ Directive 95/46/EC of the European Parliament and of the Council of 24 October 1995 on the protection of individuals with regard to the processing of personal data and on the free movement of such data, Official Journal L 281 , 23/11/1995 p. 0031 - 0050

${ }^{84}$ See Solove D.J. "A Brief History of Information Privacy Law” PROSKAUER ON PRIVACY, PLI, 2006; GWU Law School Public Law Research Paper No. 215. Available at SSRN: http://ssrn.com/abstract=914271

${ }^{85}$ See Art. 4 of the Proposal for a General Data Protection Regulation, and more explicitly: revised Recital 29, Council of the European Union, Letter from the Presidency to Working Party on Data Protection and Exchange of Information, 2012/0011 (COD), Brussels, 22 June 2012, at http://amberhawk.typepad.com/files/blog_june2012_eu-council-revised-dp-position.pdf

${ }^{86}$ The Art 29 Working Party, discussing the concept of personal data, agreed that in certain cases a deceased`s data could receive some kind of protection, e.g. where controller or processor may not be able to ascertain whether a person is alive or not; where data of a deceased is connected to that of a living person; where legal rules other than data protection might protect a deceased`s personal data (such as doctor-patient confidentiality). They also agreed it was open to member States to include protection of a deceased's personal data when implementing the DPD, provided it did not conflict with other Community laws. See Art 29 DP WP, Opinion 4/2007 on the concept of personal data, 01248/07/EN WP 136, p. 22, also pp. 16, 22, 23, citing ECJ ruling in Lindquist case: C-101/2001 of 06/11/2003, § 9.

${ }^{87}$ Article 28 (3) Bulgarian Personal Data Protection Act, State G8azette No. 1/4.01.2002, 70/10.08.2004, 93/19.10.2004, 43/20.05.2005, 103/23.12.2005, 30/11.04.2006, available in English at: http://legislationline.org/topics/country/39/topic/3 accessed 15 July 2012

${ }^{88}$ Estonia, Personal Data Protection Act, RT1 I 2003, 26, 158, RT I 2004, 30, 208, available in English at: 2http://www.legaltext.ee/text/en/X70030.htm accessed 20 July 2012

${ }^{89}$ Ibid, Article 13(1)

90 Section 3, Sweden, Personal Data Protection Act (1998:204), available in English at: http://www.sweden.gov.se/content/1/c6/01/55/42/b451922d.pdf accessed 30 July 2012
} 
"data which relate to a living individual" " Other member states also predominantly use the term "natural person", which is understood generally as meaning a person having legal capacity, starting with birth and ending with death. ${ }^{92}$

Should personal data of decedents be protected? As with the discussion earlier on emails as property, there are good arguments for and against. At a conceptual level, in common law systems, there is a long recognised principle of actio personalis moritur cum persona (personal causes of actions die with the person, e.g. defamation claims, breach of confidence claims) ${ }^{93}$. On the other hand many EU nations are of the civilian tradition which has historically been more inclined to recognise the persistence of rights to protect reputation after death, and especially a creator's interest (or rather his family's) in protecting the integrity of their creation after death. For example in the German Mephisto ${ }^{94}$ and Marlene Dietrich cases ${ }^{95}$, the courts granted protection for both the non-commercial (dignity, privacy) and commercial interests of deceased (the use of name, voice, or image for financial gain) ${ }^{96}$. However, the courts of France, another major civilian jurisdiction, took a different position. In the case of SA Editions Plon v. Mitterand", Court of Cassation held that "the right to act in respect of privacy disappears when the person in question, the sole holder of that right, dies".

Looking at policy-based arguments, some argue that the living are entitled to shape their image and protect their dignity after death; that, following the principle of freedom of testation, the wishes of the deceased should be respected; and that protecting the privacy of the deceased also protects the mourning family. Alternately however, it might be said that the privacy of the dead may conflict with the wishes and needs of the living - we have already seen this argument in the context of cases like Ellsworth, where the deceased might have wished to hide e.g. his sexuality or moral choices from his family after death. Another strong argument is that post-mortem privacy might impede freedom of expression, and further a "PR" society. Archives and the historical record would be less complete if personal data were cloaked by privacy post mortem. Society has a right to know about its history and what art and literature its deceased citizens have left as a matter of public interest ${ }^{98}$.

Finally giving rights in personal data to the deceased creates practical problems. Who is to give the consent of the deceased to use of their personal data -what heirs or representatives,

\footnotetext{
${ }^{91}$ Section 1 (1) (e) , UK Data Protection Act 1998

${ }^{92}$ Article 29 Working Party, Opinion 4/2007 on the concept of personal data, 01248/07/EN WP 136, p 22. There is also an attached issue as to when children have capacity to be exercise data protection rights.

${ }^{93}$ The principle has been revised in the UK and now only pertains to the causes for action for defamation and certain claims for bereavement. See the Law Reform (Miscellaneous Provisions) 1934 Act, Race Relations Act 1970, Sex Discrimination Act 1975, Disability Discrimination act 1995 and Administration of Justice Act 1982

${ }^{94}$ Mephisto, BVerfGE 30, 173, Federal Constitutional Court (First Division), 24 February 1971, translated by J. A. Weir: "It would be inconsistent with the constitutional mandate of the inviolability of human dignity, which underlies all basic rights, if a person could be belittled and denigrated after his death. Accordingly an individual's death does not put an end to the state's duty under Art. 1 I GG to protect him from assaults on his human dignity".

${ }_{95}$ Marlene Dietrich Case BGH 1 ZR 49/97, 01 December 1999, translated by Raymond Youngs

${ }^{96}$ Ibid, Judgement: “...b) The components of the right of personality which are of financial value remain after the death of the holder of the right of personality, at any rate as long as the non-material interests are still protected. The corresponding powers pass to the heir of the holder of the personality right and can be exercised by him in accordance with the express or presumed will of the deceased."

${ }^{97}$ SA Editions Plon v. Mitterand (Civ. 1, 14 December, 1999, Bull. no. 345), Translated French Cases and Materials under the direction of Professor B. Markesinis and M. le Conseiller Dominique Hascher, Translated by: Tony Weir at http://www.utexas.edu/law/academics/centers/transnational/work new/french/case.php?id=1240

${ }^{98}$ See further, Mazzone supra n 8, at 1652-1660.
} 
and for how long? Are the heirs required to give consent as they wish or only in accordance with what they think the wishes of the deceased were? How can conflicts between different family members be resolved, or family members and partners or friends? How can service providers know what requests are genuine and which backed by law? At present service providers, as noted above, request a variety of information from relatives, from newspaper obituaries to death certificates to mere knowledge of the deceased's email address. Formal recognition of protection of the personal data of the dead would surely require a more rigorous approach to be taken ${ }^{99}$.

As noted above, some US commentators have already been driven by the Ellsworth case to speculate on whether the wishes of the living or the privacy of the deceased should take priority. Wilkens describes privacy and access as "two ships crashing in the night" and argues that online service providers, especially financial institutions, will hesitate to provide essential records and assets to executors for fear of breaking regulations safeguarding financial privacy, such as the US Gramm-Leach-Bliley Act (GLBA). Darrow and Ferrera, by contrast, probably represent the majority American academic view in regarding privacy rights as ceasing upon death and so presenting no opposition to the will of the living. They note that private letters, diaries, and photographs can already be inherited and may contain equally private information concerning the deceased. ${ }^{100}$ However in these cases, it may be argued that the deceased either chose to allow (if a will was made) or at least did not explicitly forbid (by failing to make a will and dying intestate) the transmission of the data. Where the most acute difficulties are likely to arise are where the deceased has made it clear before death that they value their privacy (much as Nabokov made it plain he did not wish his unfinished novels to be published after his death $\left.{ }^{101}\right)$.

Darrow and Ferrera do toy with the idea that on general freedom of contract principles, "it may still be possible to create a contractual right of privacy which is effective to protect private information of deceased individuals." But, even if wishes for post mortem privacy had been incorporated into a service provider contract, or a will, it seems unlikely a court would truly prefer the wishes of the dead to those of the living, where only the living remain to suffer emotional distress. Such conflicts recall disputes over organ donation requests and family wishes eg when deceased dies with Kidney Donor card but family wish him to be buried intact ; in England, statute and medical practice still effectively resolve these conflicts in favour of the living family's wishes rather than the deceased, but in Scotland the law has now been changed to reflect the alternative position ${ }^{102}$. Finally the possibility exists that even

\footnotetext{
${ }^{99}$ See ibid at $1665-1666$ on the very rigorous materials required by Gmail before they will let heirs obtain a deceased's emails, compared to the complete lack of information given by Google (again!) re how to obtain disposition of a Blogger blog after death. Mazzone , $n$ 8, cites LinkedIn as requiring only knowledge of a deceased's email address to close their Linked In profile. Facebook has already had to deal with cases of hoax requests for deletion on death as a kind of "denial of service" attack: see eg http://gizmodo.com/5973270/itssuper-easy-to-lock-people-out-of-their-facebook-accounts-by-claiming-theyre-dead .

${ }^{100}$ See Restatement (Second) of Torts $\S$ 652I (1977); Bick, supra note 62. 163. See, e.g., Humphreys v. DeRoss, 790 A.2d 281, 289 (Pa. 2002) (Castille, J., dissenting) ("Personal belongings, letters, mementos, family photographs and the like are all common bequests . . . .); In re Mildrexter, 971 P.2d 758, 759 (Kan. App. 1999); Monk v. Monk, No. CA97-04-039, 1997 WL 700061, at*1 (Ohio App. Nov.10, 1997) in ibid p 313

${ }^{101}$ See supra $n 6$.

${ }^{102}$ See discussion in Human Tissue Authority, Code of Practice 2: Donation of Solid Organs for Transplantation, paras 96-100 at http://www.hta.gov.uk/legislationpoliciesandcodesofpractice/codesofpractice/code2donationoforgans.cfm?faAre

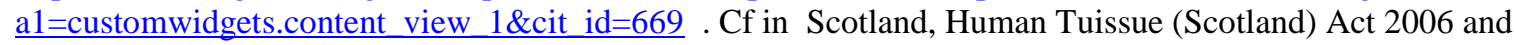
guidance at http://www.hta.gov.uk/_db/_documents/Information_about_HT_\%28Scotland\%29_Act.pdf esp. para 14.
} 
willing disclosure of emails left by a deceased may also invade the privacy of unwilling third parties; here the practical difficulties of post mortem consent for service providers become even more profound.

\section{G. Some interim solutions}

What solutions exist for the problems of post mortem transmission of digital assets and post mortem privacy? This brief review of legal issues cannot in the space allowed be comprehensive on future possible solutions. A number of suggestions however come up again and again in the literature, and are here arranged according to Lessig's famous range of modalities of regulation ${ }^{103}$.

a. LAW: Harmonise international rules to create a requirement on service providers to give access to digital accounts and assets to properly accredited representatives of the deceased. As noted above, while tailored legislation is beginning to emerge in the US, in a domain of intangible delocalised assets, piecemeal disparate local legislation is highly unsuitable. It is time the matter was brought to the table of the major treatymaking bodies, notably the Hague Conference on Private International Law, as well conceivably as the EU, the Council of Europe, the Art 29 Data Protection Working Party, the Internet Governance Forum and even the ITU. In a highly controversial area, one place to start might be with a simple uniform rule that a deceased's emails (and other digital accounts and assets?) cannot be deleted until a certain time after death, so that assets are not destroyed before relatives find out what to do, and if necessary, what court orders can be obtained.

b. LAW IMARKET/CODE: Require service providers to offer users an easy to understand and sufficiently prominent opportunity to make an election as to what happens to their digital assets after they die. In the most obvious analogy, Facebook continually offer users opportunities to alter settings concerning their privacy, the layout of their profile, what appears on the timeline, etc. Although the default and design of these settings and their impact on privacy are themselves controversial ${ }^{104}$, there seems no good reason why a pre-mortem choice could not be added, eg allowing users to appoint a "Facebook executor" ${ }^{105}$ after death, and/or to choose between (say) preservation, memorialisation or deletion of their profile themselves. This would at least overcome the prevalent problem of users, especially the young, dying without giving any evidence as to their post mortem privacy wishes. Ideally, market competition would lead to this solution; but this is probably unlikely, given the monopolistic nature of network oriented industries such as social networks, user ignorance and the likely stiff opposition from service providers, who know that reminding their customers of their mortality is hardly the most cheerful sight on a social networking site. One key issue will be if a default is set, and if so, what. Mazzone suggests interestingly that the default setting should bear community interests in mind (eg the surviving family, the public interest) while the user's explicit non-default choices could be tailored purely to their wishes.

\footnotetext{
${ }^{103}$ Lessig L. Code and other laws of cyberspace (“Code 2.0”) (Basic Books, $2^{\text {nd }}$ edn, 2006)

${ }^{104}$ See further Edwards L. "Anti-social networking” in Brown I. ed Research Handbook on Internet Governance (Edward Elgar, forthcoming 2013).

${ }^{105}$ An obvious problem might be if such an election meets the formal requirements of a will to be in "writing" in most jurisdictions - and the possibility of conflict with "hard copy" wills. A truly radical solution would be to encourage users to make electronic wills (deemed formally valid) as part of the online social networking experience. (or on phones via apps, or via the digital will drafting services mentioned above.)
} 
c. CODE: Using digital wills/trusts etc. A number of digital services have emerged in recent years to try, in the main absence of legal assistance, to solve the problems of transmission of digital assets. as digital assets. These include "password lockers", online will drafters and post-mortem emailers, as well as various hybrids (e.g. Asset Lock, Entrustet, LifeEnsured, Death Switch, My Digital Executor, Final Fling). Unsurprisingly, given the terrain surveyed above, these are not themselves a foolproof solution. Passing on a password may be a breach of terms of service, a criminal offence or inconsistent with the law of succession/executry (e.g. engaging conflicts with who is the heir on intestacy or under a written will, requirements of will formalities, jurisdiction issues etc.) Other concerns include the stability and longevity of the market and individual services, security, identity theft etc.). However, with the assistance of law (as in suggestions a. and b. above), these code solutions could, arguably, be appropriate for the online environment and enable more efficient and accessible transmission of certain digital assets.

d. NORMS: Education and training. It goes without saying that better public and indeed, lawyer, and policymaker, awareness of some of these issues would help resolve them before disputes arise. Service providers should make their policies on death clearer and more transparent (or indeed, create some if none exist); train their response or abuse teams to deal with these issues; and offer help to users. Providing information to children and young people should be a priority. Call centre and helpline staff at online banks, ISPs, webmail service providers etc are also likely to be in need of appropriate training and resourcing.

However as in all aspects of Internet and social networking culture, education is unlikely to be the complete answer, nor is the market, and it is the authors' view that regulation (and possibly transnational legislation), further than mere "nudging" of the market, is likely to become necessary sooner rather than later. With successive generations increasingly banking online, creating online, communicating online and playing online, the problem of death and digital assets, like death itself, is not likely to go away any time soon. 